\title{
How skin and liver can lead to diagnosis
}

\author{
P. Vande Berg ${ }^{1}$, A. Vande Berg ${ }^{2}$, E. Harkemanne ${ }^{3}$, C. Peeters ${ }^{3}$, V. Havelange ${ }^{4}$, N. Lanthier ${ }^{1}$
}

(1) Service d'Hépato-Gastroentérologie, Cliniques universitaires Saint-Luc, UCLouvain, Brussels, Belgium; (2) Service d'Anatomie Pathologique, Cliniques universitaires Saint-Luc, UCLouvain, Brussels, Belgium; (3) Service de Dermatologie, Cliniques universitaires Saint-Luc, UCLouvain, Brussels, Belgium; (4) Service d'Hématologie, Cliniques universitaires Saint-Luc, UCLouvain, Brussels, Belgium.

A 73-year-old woman was referred by her hematologist for cholestasis of unknown origin. She was recently diagnosed with chronic myelomonocytic leukemia grade 0 in a context of fatigue, night sweats, weight loss and monocytosis. A PET-CT showed hepatosplenomegaly and multiple centimetric adenopathy. The diagnosis was confirmed by a bone marrow aspiration and biopsy.

Interestingly, the evolution of the patient is marked by the appearance of cholestasis and an erythematous firm skin nodule of the right forearm. The skin lesion was biopsied to rule out a cutaneous localization of the patient's known hemopathy. Histology showed an
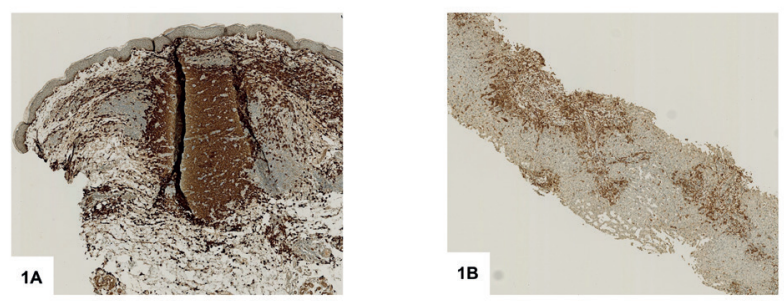

Figure 1. - Skin nodule biopsy revealing a massive infiltration of the dermis with CD117 positive cells (A) and liver biopsy showing an impressive presence of CD25 positive cells within the portal tract and extending in the liver lobule (B).

Table 1. - Main hematological, systemic and autoimmune diseases affecting the skin and the liver

\begin{tabular}{|c|c|c|}
\hline Disease & Skin manifestation & Liver finding \\
\hline \multicolumn{3}{|l|}{ Hemopathies } \\
\hline - Lymphoma & Pruritus, erythematous patches, plaques and nodules & Nodules, mass \\
\hline - Langherans cell histiocytosis & Brown to purplish papulonodular eruption & $\begin{array}{l}\text { Diffuse liver infiltration, nodules, sclerotizing } \\
\text { cholangitis }\end{array}$ \\
\hline - Malignant histiocytosis & Ulcerated lesions, erythematous plaques & Peliosis hepatis \\
\hline - Systemic mastocytosis & Maculopapular eruption, mastocytoma, pruritus & Portal hypertension, cholestasis \\
\hline \multicolumn{3}{|l|}{ Systemic diseases } \\
\hline - Sarcoidosis & $\begin{array}{l}\text { Papular lesions, nodular lesions, plaque-like lesions, } \\
\text { lupus pernio, erythema nodosum, subcutaneous nodules }\end{array}$ & $\begin{array}{l}\text { Cholestasis, cirrhosis, hepatic vein thrombosis, } \\
\text { portal hypertension }\end{array}$ \\
\hline - Crohn's disease, Ulcerative colitis & $\begin{array}{l}\text { Erythema nodosum, pyoderma gangrenosum, } \\
\text { Sweet syndrome }\end{array}$ & Primary sclerosing cholangitis \\
\hline \multicolumn{3}{|l|}{ - Vasculitis } \\
\hline - Periarteritis nodosa & $\begin{array}{l}\text { Erythematous nodules, ulcerated lesions, purpura, } \\
\text { petechial rash, livedo reticularis }\end{array}$ & Aneurysm of hepatic artery \\
\hline$\circ$ Giant cell arteritis & Erythematous nodules, ulcerated lesions, purpura & Cholestatis, nodules, biliary stenosis \\
\hline \multicolumn{3}{|l|}{ Autoimmune disease } \\
\hline - Lupus erythematosus & $\begin{array}{l}\text { Butterfly shaped facial rash, discoid lesions, papulo- } \\
\text { squamous lesions }\end{array}$ & Hepatitis \\
\hline - Systemic sclerosis & $\begin{array}{l}\text { Pruritus, hyper- or depigmentation, ulcerations, skin } \\
\text { sclerosis, subcutaneous calcifications }\end{array}$ & $\begin{array}{l}\text { Overlap with primary biliary cholangitis (Reynolds } \\
\text { syndrome) }\end{array}$ \\
\hline - Sjögren's syndrome & $\begin{array}{l}\text { Raynaud's phenomenon, purpura, ichtyosis, association } \\
\text { with other auto-immune diseases i.e., systemic lupus } \\
\text { erythematosus, systemis sclerosis }\end{array}$ & Cholangitis, hepatitis \\
\hline
\end{tabular}

infiltration of the dermis with a population of immature cells. The immunohistochemical analysis of those cells showed positive CD117 (Fig. 1A) and CD4 staining leading to the diagnosis of a skin localization of the chronic myelomonocytic leukemia.

Given the persistence of cholestasis (alkaline phosphatases at $737 \mathrm{IU} / \mathrm{L}$ and gamma glutamine transferase at $119 \mathrm{IU} / \mathrm{L}$ ), a transvenous liver biopsy was performed. Hepatic venous pressure gradient was $10 \mathrm{mmHg}$. Histo- logy revealed a cellular infiltration of the portal tracts. The immunohistochemical analysis showed massive liver infiltration of CD117 and CD25 positive cells (Fig. 1B).

\footnotetext{
Correspondence to : Dr Perrine Vande Berg, Ormendaal 17, 3060 Korbeek-Dijle, Belgium.

E-mail : perrinevandeberg@icloud.com

Submission date : 01/02/2021 Acceptance date : 08/03/2021
} 
Ductular proliferation with ductular damage, neutrophilic inflammatory infiltrate and dissecting fibrosis of the portal spaces was also present. What's your diagnosis?

Many hematological, systemic and autoimmune diseases can affect the liver and skin (Table 1). The presence of clusters of abnormal reactive and neoplastic mast cells with positive immunohistochemical staining for CD117 and CD25 in the liver is compatible with a systemic mastocytosis with an associated hematologic neoplasm (SM-AHN) (1,2). When skin and bone marrow histology were revised (after liver histology), CD25 immunohistochemistry showed multifocal CD25 positive clusters of abnormal mast cells. Serum tryptase was elevated at 192,0 microg/L. KITD816V mutation was present. Treatment with midostaurine was started. She was non-responder and a second line therapy with avapritinib (in compassionate use) was started leading to the normalization of liver tests. The patient is still alive, after 2 years of follow up. Systemic mastocytosis is an infiltration of different organs by mast cells. Liver damage is common and can present as hepatomegaly, disturbance of liver enzymology, portal hypertension or hepatocellular insufficiency (3). Histology may show an infiltration of the portal spaces or sinusoids, cholestasis, cholangitis, nodular regenerative hyperplasia, septal and peri-sinusoidal fibrosis, veno-occlusive disease and secondary extramedullary hematopoiesis.

Keywords: cholestasis, skin lesion, systemic mastocytosis, avapritinib.

\section{Conflict of interest statement}

No conflict of interest.

\section{References}

1. PARDANANI A. Systemic mastocytosis in adults: 2019 update on diagnosis, risk stratification and management. Am J Hematol, 2019, 94: 363-377.

2. HORNY P., SOTLAR K., VALENT P. Mastocytosis: Immunophenotypical Features of the Transformed Mast Cells Are Unique Among Hematopoietic Cells. Immunol Allergy Clin North Am.,2014, 34: 315-321.

3. WENDUM D., PREVOT S., POUJOL-ROBERT A., ROSMORDUC O., CABANE J., FOUILLARD L., et al. Liver involvement revealing systemic mastocytosis: report of two cases. Gastroenterol Clin Biol., 2004, 28: 80-83. 